\title{
Kohti digitaalista oppimisteollisuutta ketä varten, kenen ehdoilla?
}

\author{
Jarmo Viteli ja Jarmo Levonen
}

\section{Learning is what most adults will do for a living in the 21 st century.}

—Sidney Joseph Perelman

\section{Digitaalinen oppimisteollisuus ${ }^{1}$}

$\mathrm{T}_{\mathrm{n}}$ ieto- ja viestintätekniikka ovat nopeasti muuttamassa koulutussektoria. Oppimisen ja opetuksen toteuttamisen moninaiset tieto- ja viestintätekniikan sovellukset ovat kehittyneet tutkimus- ja kehittämishankkeista kaupallisiksi sovellutuksiksi ja palveluiksi. Erilaiset inter- ja intranet sovellukset, kuten verkkopohjaiset oppimisympäristöt, työryhmäohjelmistot ja tietojärjestelmien internet-sovellukset ovat helposti ostettavissa tai tilattavissa palveluina.

Internetin ja muiden online-informaatiojärjestelmien käyttö on myös vaativa käyttäjille. Informaation määrä lisääntyy eksponentiaalisesti ja samalla meillä on yhä vaikeampaa erottaa olennainen epäolennaisesta. Koulutuksen kentällä vallitsee myös yhä laajeneva kokonaisuuksien hallinnan puute. Uusia oppimisympäristöjä ja muita informaatiojärjestelmiä esitellään tasaiseen tahtiin ja niiden käyttöönottoa edellytetään kiihtyvään tahtiin. Nopeasti muuttuva toimintaympäristö asettaa opettajat ja tutkijat tilanteeseen, jossa pelkkä teknologian muutosten hallinta vie kaiken ajan ja energian.

Kehitykselle on tyypillistä, että ilmiöiden jälkikäteinen tutkimus ei välttämättä annakaan enää mahdollisuuksia ennakoida tulevaa. Koulutussektorin ja informaatioteknologian yhteiselämä näyttää vahvasti teknologiavetoiselta vai muistaako kukaan informaatioteknologista innovaatiota, joka olisi tehty opettajien toiveesta saati tutkijoiden saamien tutkimustulosten perusteella edistämään oppimista ja opetusta?

$\mathrm{T}$ ieto- ja viestintätekniikan mahdollisuudet koulutuksessa kiinnostavat myös muita kuin opettajia ja opiskelijoita. Digitaalinen oppimisteollisuus $^{2}$ on vahvasti syntymässä ja sen toimijat ovat sekä perinteiseltä kustannussektorilta, mutta erityisesti konvergoituneen tieto- ja viestintätekniikka sektorin yrityksiä. Yhden johtavista amerikkalaisista investointipankeista, U.S. Bancorp Piper Jaffray ${ }^{3}$, toimesta on tehty analyysi, jossa tarkastellaan mm. mitkä tekijät edesauttavat sähköisten oppimisympäristöjen leviämistä (ks. taulukko 1) oppijan ja digitaalisten oppimisympäristöjen toimittajan näkökulmasta (Peterson, Marostica, \& Callahan 1999, November). Analyysi osoittaa, että digitaalinen oppimisteollisuus on tullut mahdolliseksi, kun koulutuksen ja tietokoneiden käyttökulttuurin laajentumisen vaikutuksesta oppijoiden ${ }^{4}$ teknologiataidot ovat kehittyneet ja oppimisympäristöjen ja niihin toimitettavan sisällön kehittäminen on joustavien medioiden johdosta tullut kannattavaksi. 
Analyysissään investointipankin tutkijat päätyvät ennustamaan, että sähköiset oppimisympäristöt ovat Internetin merkittävä liiketoimintaalue, yksi voimakkaimmin kasvavista uuden teollisuuden alueista seuraavien vuosien aikana.

$\mathrm{D}$ igitaalisen oppimis- ja opetustoiminnan arjoajien ja asiakkaiden asettuminen yhteiselle areenalle on olennainen ehto (ks. taulukko 1), jotta uusi liiketoiminta voisi toteutua. Voidaan myös kysyä, tuoko digitaalinen oppimisteollisuus jotain uutta oppimisen- ja opetuksen käytäntöihin. Asiakkaiden, eli oppijoiden näkökulmasta voidaan arvioida, millainen merkitys on opetuksen erilaisilla "jakelujärjestelmillä", kuten verkkopohjaisella "online", opettaja-joh- toisella tai CD-ROM-pohjaisella "offline" oppimisella (ks. taulukko 2) (Peterson et al. 1999, November).

Arvio osoittaa, että ainakin valittujen tekijöiden osalta e-learning näyttää toimivalta opetuksen jakelujärjestelmältä. Vakava kysymys on tietenkin se, että voidaanko ja kuinka perusteltua on oppimisen ja opetuksen maailman tarkastelu puhtaan jakelujärjestelmän näkökulmasta. Tarkastelukulma kertoo myös vahvaa viestiänsä siitä, mistä perusolettamuksista opetuksen ja oppimisen suhteen arvioijat ovat liikkeellä. Yhteiskunnan kannalta onkin erityisen haasteellista pohtia, miten opetuksen ja oppimisen perusolettamukset kestävät kun uusi digitaalinen oppimis-

Taulukko 1. Digitaalisen oppimisen kehittymisen vaikuttajat, soveltaen (Peterson et al. 1999, November).

\section{Digitaalisen oppimisen toteuttajat oppijan (e-learner) näkökulmasta}

1 Teknologiaorientoitunut nuoriso

1 Elinikäinen oppiminen välttämätöntä nykypäivän kilpailussa työmarkkinoilla

1 Kiireiset elämäntyylit - ei aikaa $(24 \times 7 \times 365)$

1 Digitaalinen oppiminen tukee kollaboraatiota

1 Matkustuskustannuksien ja ajan säästö, kustannussäästö ja tuottavuuden kasvu

1 Missä tahansa paikassa, omaan tahtiin, milloin vain

1 Personalisointi

1 Vanhemmat haluat parasta opetusta lapsilleen

1 Halu saada lisää informaatiota ja resursseja 1 Webin yhteisöllisyyden orientaatio tuo oppijat yhteen

1 Intuitiivinen oppimisympäristö

1 Nykypäivän oppijat kasvavat webin kanssa, tuttuus auttaa siirtymään digitaaliseen oppimiseen

1 Webbi toimii "komentokeskuksena" nykypäivän oppijoille, luoden mahdollisuuksia toteuttaa alustalla sekä oppimista että leikkiä

\section{Digitaalisen oppimisen tarjoajat oppimisympäristöjen toimittajan näkökulmasta}

1 Sisällön päivittämisen helppous ja muutokset ovat välittömästi nähtävissä

1 Avoimet verkkopohjaiset oppimisympäristöt tukevat joustavaa ja täsmäajoitettua tukea oppijoille. Vahvistaa yhtenäisen sisällön kehittämistä ja ylläpitoa

1 Useita tulolähteitä (e-commerce, ilmoitukset, tilaukset, lisensointi)

1 Huomioi muuttuvan demografian: enemmän teknologiataitoisia ylioppilaita, lisää työelämään osallistuvia aikuisia

1 Edullinen maailmanlaajuinen jakelukanava (s.o. ei ole tarvetta erillisille jakelumekanismeille, esim. CD-ROM tietokoneavusteisessa opetuksessa)

1 Voi toteuttaa useassa eri tietokoneympäristössä, ei vaadi eri versioita jokaiselle käyttöjärjestelmälle - Webbi-pohjaista opetusta voi toteuttaa kaikilla webbiselaimilla ja kaikilla käyttöjärjestelmissä (Windows, MAC, Unix, etc.) 1 Tekee mahdolliseksi muokkaamisen ja personoinnin

1 Informaatiolle lisäarvo (esimerkiksi tilausten vastaanotto)

1 Varmistaa opetusmateriaalin yhdenmukaisen toimittamisen 
Taulukko 2. Oppimisen ja opetuksen jakelujärjestelmien vertailua, soveltaen (Peterson et al. 1999, November)

\begin{tabular}{|c|c|c|c|}
\hline & $\begin{array}{l}\text { Digitaalinen oppiminen } \\
\text { (E-learning) = Webbi- } \\
\text { pohjainen tai -tuettu } \\
\text { oppiminen }\end{array}$ & $\begin{array}{l}\text { Opettaja- } \\
\text { johtoinen } \\
\text { opetus }\end{array}$ & $\begin{array}{l}\text { CD- } \\
\text { ROM }\end{array}$ \\
\hline $\begin{array}{l}\text { "Hardware" ja "Software" vaatimukset } \\
\text { Kurssin saavutettavuus (Access) } \\
\text { Ohjaajan vuorovaikutus } \\
\text { Kustannukset } \\
\text { Dynaaminen ja ajankohtainen sisältö } \\
\text { (versiointi) } \\
\text { Skaalattavuus } \\
\text { Vuorovaikutus toisten oppijoiden kanssa } \\
\text { Kurssin päivitysten välitön saatavuus } \\
\text { Suorituksen / tulosten seuranta } \\
\text { Säilyvyys (Consistency) (ohjaus ja formaatti) } \\
\text { Säilyttäminen (Retention) } \\
\text { Joustavuus oppijalle (aika, jne.) } \\
\text { Sisällön määrä } \\
\text { Yksilöinti }\end{array}$ & $\begin{array}{l}+ \\
++++ \\
+++ \\
++++ \\
++++ \\
++++ \\
+++ \\
++++ \\
++++ \\
++++ \\
++++ \\
++++ \\
+ \\
++++\end{array}$ & $\begin{array}{l}+++ \\
0 \\
++++ \\
+ \\
++ \\
+ \\
+++ \\
0 \\
++ \\
++ \\
+ \\
++ \\
++++ \\
0\end{array}$ & $\begin{array}{l}++ \\
+ \\
0 \\
++ \\
+ \\
++ \\
0 \\
0 \\
+ \\
++++ \\
++ \\
++++ \\
++ \\
+\end{array}$ \\
\hline
\end{tabular}

teollisuus laajentuu globaalisesti. Uhka saattaa piillä mekanistisissa oppimiskäsityksissä ja uusien oppimisympäristöjen "tehokkaissa standardiratkaisuissa", jotka eivät yleisyyden, yksinkertaisuuden yms. johdosta sovellu korkeatasoisen opetuksen ja syvällisen oppimisen toteuttamiseen ${ }^{5}$. Digitaalisen oppimisteollisuuden taloudellisista mahdollisuuksista luodaan raporteissa hyvin positiivinen kuva, mikä varmaan saa liikkeelle yhä uusia yrittäjiä. Kuten on viimeaikoina havaittu, uudet informaatioteknologia-alueen avaukset ovat keränneet kansainvälisissä pörsseissä suuria odotusarvoja ja toiveita. Samoin tapahtunee digitaalisen oppimisteollisuuden alueella. Opetuksen ja oppimisen maailma näyttää kiinnostavan paljon muitakin kuin opettajia, tutkijoita ja poliitikkoja juhlapuheissaan.

\section{"Learnativity" - Oppiminen digitaalisessa maailmassa}

Tieto- ja viestintätekniikan käyttöönoton vai- kutuksesta organisaatiot ovat muuttuneet ja muutos on seurannut myös useita työtehtäviä. Työntekijöille usein esitettyjä vaatimuksia on digitaalisen maailman muutoksien mukana pysyminen ja uusien toimintaympäristöjen ja mallien nopea haltuunotto. Kysymys on oppimisesta, siitä miten oppija kykenee tehokkaasti hyödyntämään uusia tietojärjestelmiä, miten oppija perehtyy uuteen työympäristöön tai miten oppija uudistaa työprosessejaan käyttämällä uusia toimintamalleja.

Yhdysvalloissa ilmestyi helmikuussa 2000 tulevaisuuden tutkimus ja visiopaperi ${ }^{7}$, jonka American Society for Training and Development (ASTD) yhdessä National Governors Associationin (NGA) kanssa teetti alan tutkijoilla ja kehittäjillä aiheesta "The Commission on Technology and Adult Learning"8 (Hodgins 2000, February). Raportin taustalta löytyy myös vaikuttavia yritysmaailman edustajia. Raportti kiteytyy uuteen käsitteeseen tulevaisuuden oppimistoiminnasta: "Learnativity". Uuden oppimiskäsit- 
teen lähtökohtina ovat mm. seuraavia olettamuksia (Conner 1996; Hodgins 2000, February):

1 Teknologiaa käytetään jo laajasti aikuiskoulutuksessa. Se kasvaa suhteellisen "vapaamuotoisena" ja ulkopuolella perinteisen sosiaalipoliittisen kentän.

1 Muutos "opetuksesta (education) ja koulutuksesta" "tietämyksen hallintaan" on nähtävissä

1 Harppauksia lajittelun, haun ja datan uudelleen käytön menetelmien kehittymisessä on tapahtunut kun on sovellettu ns. "objektiorientoituneita" menetelmiä

1 Internet ja multimedia materiaali ja menetelmät ovat muodostuneet tärkeiksi aikuiskoulutuksessa

1 Erilliset teknologiat ja organisaatiot liittyvät yhteen luomaan moninaisia multimedian toimitusväyliä aikuiskoulutuksen sisällöille

1 Langaton aikakausi ja laajakaistayhteyksien käyttö ovat nykyaikaa, jolloin sekä yksiköt että organisaatiot voivat merkittävästi laajentuneiden yhteyksien kautta päästä informaation lähteille kotoa, työpaikoilta, kouluista - kaikkialta.

1 Useat opettajat ja teknologian asiantuntijat työskentelevät yhdessä luodakseen menetelmiä ja standardeja, jotka tekevät mahdolliseksi sisällön helpon uudelleen käytön, yhdistelemisen ja siirtämisen yksilöiden, instituutioiden ja maiden välillä.

$\mathrm{M}^{\mathrm{s}}$ onista yllä kuvatuista seikoista voidaan Suomenkin kontekstissa olla samaa mieltä. Visiopaperin laatijat jatkavat kuitenkin pidemmälle ja nostavat uuden elämisen muodon - "learnativityn" - esille. Se on heidän mielestään seuraava konvergenssin muoto, jossa aikuiset, teknologia ja learnativity yhdistyvät. Learnativity koostuu oppimisesta (learning), tiedonhallinnasta (knowledge management), tiedon kiteyttämisestä (capturing) ja tekemisestä (performance). Nämä learnativityn eri osatekijät ovat jatkuvassa vuorovaikutuksessa ja toiminnassa keskenään. Learnativity on elämäntyyli, jossa olemme jatkuvassa prosessissa oppimassa uusia tietotaitoja ja teknologia on asetettu tukemaan meitä tässä oppimisprosessissa.
Taustalla on ajatus tietämysyhteiskunnasta ("Knowledge Society"), jossa tieto on yhteiskunnan polttoaine ja uutta tietoa tarvitaan yhä tehokkaammin. Sen hankkimiseen ei riitä enää formaalit opinnot vaan sitä on kehitettävä jatkuvasti, jotta pystyttäisiin yhä parempiin suorituksiin. Learnativity pohjaa optimistiseen käsitykseen mahdollisuuksistamme ja teknologiasta osana tätä prosessia.

Meillä ja maailmalla on ladattu paljon odotuksia teknologian mahdollisuuksiin oppimisen maailmassa. Ennusteet, joiden mukaan 30 vuoden päästä vain viisi prosenttia työnteosta olisi fyysistä, korostavat tiedon ja informaation merkitystä huomisen yhteiskunnassa. Oppiminen ja osaaminen nähdään merkittävimmiksi kilpailutekijöiksi ja oppimista tukevalle teknologialle annetaan paljon odotusarvoa.

Valitettavasti tiedämme vielä varsin vähän teknologiaintensiivisten oppimisympäristöjen toimivuudesta oppijan ja oppimisen kannalta. Ehkäpä siksi tutkijat ja opettajat eivät ole kyenneet astumaan esiin ja sanomaan, millaista teknologiaa ja miten käytettynä saisimme aikaan toivottuja tuloksia. Jatkossa näemme entistä voimakkaamman kaupallisten toimijoiden esiinmarssin opetussektorille, erityisesti aikuiskoulutusmarkkinoille. Auttaako meitä silloin eilisen tieto kertomaan, mitkä ratkaisut ovat toimivia vai tarvitaanko myös konstruktiivista, uutta luovaa tutkimustoimintaa, jolloin tutkijat voisivat takarivistä nousta, ei vain asioiden toteajiksi, vaan myös suunnannäyttäjiksi. Aika näyttää. 


\section{Lopuksi}

$\mathrm{O}$ rganisaation näkökulmasta katsottuna verkkoja hyödyntävien oppimisympäristöjen käyttöönotto ja hyödyntäminen voi palvella samanaikaisesti useita eri organisaation tarpeita, kuten kommunikaatiota, koulutusta, tiedottamista, yhteisten tavoitteiden ja kulttuurin kommunikointia jne. Kehityksen hidasteena voi olla organisaatioiden vaikeus löytää soveltuvia henkilöresursseja luomaan kollaboratiivisten verkkojen käyttöönottostrategiaa. Tarvitaan myös uudenlaista ajattelua henkilöiden rekrytoinnissa, tarvitaan “organisaatioiden saattajia (escorts)", joilla on sekä tietoteknistä ja pedagogista tietotaitoa, että organisaation sisältöalueen tuntemusta. Organisaatioiden kehittymisen arviointi on toinen olennainen huomioitava seikka verkkojen hyödyntämisessä. Tarvitaan myös tutkimuksia sekä organisaation sisällä että eri organisaatioiden välillä, jotta voidaan arvioida organisaation kehittymistä, ks. (Senge 1993). Tärkeätä on myös kyetä tunnistamaan ja arvioimaan innovaatiota, joita voi syntyä rakennettaessa uusia oppimisympäristöjä ja kehitettäessä oppimisympäristön käyttöönottoa sekä pedagogisia käytäntöjä, ks. (Lesgold 1998).

Digitaalisen oppimisteollisuuden kehityksessä on nähtävissä myös haasteita. Haasteita on digitaalisella oppimisteollisuudella, kuten standardoituminen ja keskittyminen, että digitaalisen oppimisteollisuuden vaikutuksella opetukseen ja oppimiseen perinteisissä koulutusorganisaatioissa ja yrityksissä. Seuraavassa on tarkasteltu lähemmin em. haasteita.

Standardoinnin haaste. Digitaalinen oppimisteollisuus pyrkii muodostamaan vahvoja standardeja eri digitaalisten toimijoiden välillä. Kehitys digitaalisen teollisuuden alueella on osoittanut, että standardien kehittämisen kautta on mahdollista kullekin toimijalle keskittyä lähemmin oman erityisosaamisen kehittämiseen ja luoda synergiaa usean eri toimijan erityisosaamisesta.

Keskittymisen haaste. Digitaalisen oppimisteollisuuden tavoitteena on toimia globaalisesti. Tällöin on odotettavissa, että kilpailun, synergiaetujen, yhteenliittymien yms. johdosta vain todel- liset globaalit toimijat selviytyvät. Keskittymisestä seuraa nopea taloudellinen hyöty: yhteiset rajapinnat eri sisällöntuottajien, pedagogisten ja organisaatioiden toiminnallisten mallien luojien ja oppimisympäristöihin erityispiirteitä sisältävien ohjelmamodulien toimittajien (esim. virtuaalitodellisuuskäyttöliittymä yms.) välillä kehittävät edelleen digitaalisen oppimisteollisuuden laajentumista. Pitkällä tähtäimellä keskitetyt ratkaisumallit koulutusympäristöjen standardoinnissa voivat johtaa innovaatioiden köyhtymiseen ja kehityksen hidastumiseen.

Perinteisen koulutuksen haaste. Perinteistä (lähi)koulutusta toteuttavat organisaatiot pyrkivät digitaalisen oppimisteollisuuden tuotteiden (esimerkiksi verkkopohjaiset oppimisympäristöt) avulla tehostamaan omaa toimintaansa. Erityiseksi haasteeksi muodostunee kehityksen nopeus ja intensiteetti, miten esimerkiksi perinteiset koulutusorganisaatiot kykenevät tarvittaessa nopeasti muuttamaan toimintastrategioita ja kohdentamaan riittävästi resursseja uusille alueille. Toisaalta kehitys luo pohjaa uusien koulutusorganisaatioiden ja koulutusmallien muodostumiselle. Tällainen kehitys on ollut nähtävissä jo kansallisesti, esimerkiksi Seinäjoella, minne alueen ulkopuolella toimivat korkeakoulut ovat perustaneet täydennys-, lisä- ja jatkokoulutustarpeeseen uusien yksiköitä (Helsingin, Tampereen ja Vaasan yliopisto ja Sibelius Akatemia) ${ }^{9}$.

$\mathrm{K}$ ansainvälisellä tasolla on käynnissä korkeacouluyksiköiden keskittyvä hajaantuminen. On muodostunut monikansallisia eri korkeakoulujen välisiä ja yritysten ja korkeakoulujen välisiä liittoutumia ${ }^{10}$, jotka pyrkivät keskittämään osan toimintojaan ${ }^{11}$ ja toisaalta toimimaan globaalisti ja yhä useammalla sisältöalueella.

Uudet koulutusmallit saattavat virkistää ja tehostaa perinteisten koulutusorganisaatioiden toimintaa ja tukea korkeatasoisen kansainvälisen tutkimuksen toteuttamista. Globaalin oppimisteollisuuden rinnalle voi nousta myös uusia kansainvälisiä "vapaan" ja "avoimen" koulutuksen malleja, jotka tukevat omaehtoisen ja itseorganisoituvien ryhmien ${ }^{12}$ oppimis- ja opiskelutoimintaa. Internetin kollaboratiivisen oppimisen 
parhaita esimerkkejä on Linux -käyttöjärjestelmä ja GNU-ohjelmat ${ }^{13}$.

Erikoistumista voi syntyä esimerkiksi yliopistojen ja korkeakoulujen sisällä olevien yksiköiden erikoistumisena paikallisiin (opetus suomeksi ja kansallisesti relevantti tutkimus), kansallisiin (opetus suomeksi ja tutkimus kansainvälistä), kansainvälisiin (opetus ja tutkimus kansainvälistä) tai monikansallisiin filiaaleihin (opetus ja tutkimus kansainvälistä). Kansainvälisten yliopistoyksiköiden erillisten filiaalien perustamisesta on mediassa ollut jo keskustelua. Yliopistoallianssien synergiaetujen viitoittamana voidaan yliopistojen erikoistumista ja vahvaa yhteistyötä pohtia, nykyisten yksiköiden sisällä. Ajatusleikkinä voi pohtia, esimerkiksi millaisten ominaisuuksien perusteella voitaisiin määritellä suomalaisessa yliopistossa oleva laitos, joka olisi erityisesti paikallinen, kansallinen tai kansainvälinen yksikkö. Vastaavasti voisi pohtia millaista olisi vahvojen yliopistoallianssien vaikutus yliopistojärjestelmään, esimerkiksi jos samaisessa hypoteettisessa yliopistossa olisi osa laitoksista paikallisia, kansallisia tai kansainvälisiä ja osa olisi kansainvälisesti tunnettujen yliopistoyksiköiden virallisesti valtuuttamia filiaaleja. Tällöin olisi mahdollista esimerkiksi perustaa tarvittaessa ja nopeasti tieteellisesti korkeatasoisia laitoksia ja koulutusohjelmia, joissa kansainvälinen partneri organisoisi opetuksen tietoverkkojen välityksellä ja paikallisesti toteutettaisiin koulutuksen lähijaksot.

Viimeaikainen kehitys uudessa digitaalisessa oppimisteollisuudessa antaa kuitenkin viitteitä siitä, että kehitys on erittäin nopeata ja globaalia. Suomen ja Euroopan näkökulmasta haaste on esitettävä yliopistoille ja korkeakouluille, jotka ovat keskeisessä asemassa muodostettaessa digitaalisen oppimisteollisuuden huomioivaa tutkimus- ja kehittämisstrategiaa. Aikuiskasvatus ja-koulutus ovat digitaalisen oppimisteollisuuden keskiössä, siellä missä oppija ja oppimisympäristö kohtaavat. Miten haasteeseen vastataan?

\section{Lähteet}

CONNER, M. L. (1996). Learning: The critical techno- logy: A whitepaper on adult education in the information age (Whitepaper ). St. Luis: Wave Technologies International.

HODGINS, H. W. (2000, February). Into the future: A vision paper: Commission on Technology \& Adult Learning: A Joint Project of the American Society for Training \& Development (ASTD) and the National Governors' Association (NGA).

LESGOLD, A. (1998). On evaluation of educational innovations (Working paper, March 5, 1998 ). Pittsburgh, PA: LRDC, University of Pittsburgh.

PETERSON, R. W., Marostica, M. A., \& Callahan, L. M. (1999, November) e-Learning: Helping investors climb the e-learning curve. USA: US Bancorp Piper Jaffray Equity Research.

SENGE, P. M. (1993) The fifth discipline - Art and practice of the learning organization. UK: Random House.

\section{Viitteet}

1. Mainittakoon, että kirjoittajat eivät ole digitaalisen oppimisteollisuuden sanansaattajia eikä markkinoijia. Kirjoittajat pyrkivät käynnistämään keskustelua mahdollisista tietoyhteiskunnan poluista, joista saattaa muodostua keskeinen tulevaisuuden aikuiskasvatuksellinen väylä.

2. Digitaalisella oppimisteollisuudella tarkoitetaan uutta "elearn"-teollisuutta, joka käsittää laajaalaisesti tietokoneiden, tietoverkkojen ja niihin liittyvien palvelukonseptien soveltamisesta erilaisiin oppimis-, opetus- ja koulutustehtäviin.

3. Ks. http://www.piperjaffray.com/

4. Käsitteellä oppija tarkoitetaan laajasti digitaalisen oppimisteollisuuden yhtä asiakasryhmää, eli opetuksen ja oppimisen tukemisen kohdetta, joka voi olla oppilas, opiskelija tai muu oppimista harjoittava henkilö. Joissain tapauksissa oppijayksikkö voi olla myös ryhmä, organisaatio tai yritys, vrt. oppiva organisaatio (Senge 1993).

5. Ks. esim. LEHTINEN, E., Kinnunen, R., Vauras, M., Salonen, P., Olkinuora, E., \& Poskiparta, E. (1989) Oppimiskäsitys. Helsinki: Valtion painatuskeskus.

6. Käsite "learnativity" on muodostettu yhdistämällä osat sanoista learning ja activity. Learnativitysanalla viitataan tietyntyyppiseen oppimistoimintaan. Kirjoittajat ottavat mielellään vastaan ehdotuksia suomenkielisestä vastineesta sanalle learnativity.

7. Ks. http://www.learnativity.com/download/MP7.PDF

8. Ks. http://www.performancesupport.com/ ja http:// www.learnativity.com

9. Ks. SOTARAUTA, M., Lakso, T., \& Kurki, S. (1999). Alueellisen osaamisympäristön vahvistaminen: Etelä-Pohjanmaan korkeakouluverkoston toimintamalli. Tampere: Tampereen yliopisto. Alueellisen johtamisen tutkimusyksikkö. Sente-julkaisuja $4 / 1999$.

10. Ks. esimerkiksi http://www.unext.com/ ja http:// www.cardean.com/

11. Keskittymistä voidaan toteuttaa esimerkiksi opiskelija-, talous- ym. hallinnossa, opetusmateriaalien ja -sisältöjen tuotannossa, opiskelijoiden rekrytoinnissa ja opetuksen toteutuksessa.

12. Esim. webbi-intressiryhmät ja -opintopiirit

13. Ks. http://www.linux.org/ tai http://www.gnu.org/ 